Acta regionalia et environmentalica 2

Nitra, Slovaca Universitas Agriculturae Nitriae, 2014, p. 41-51

\title{
SUSTAINABLE RURAL DEVELOPMENT POLICY IN POLAND - ENVIRONMENTAL ASPECTS
}

\author{
Józef MOSIEJ \\ Warsaw University of Life Sciences - SGGW (WULS-SGGW), Poland
}

\begin{abstract}
The author discusses issues of sustainable development in rural areas in Poland from the perspective of natural resources management. Sustainable development of rural areas is the way of managing which links economic, social and ethical principles with ecological safety. This may be reached by proper management, directed on cautious usage of ecosystems' self-controlling mechanisms, with the progress of science and technology. Agriculture in Poland is one of the most important sectors from an economic perspective and its importance is greater in Poland than in other countries in the EU. It has an influence not only on the social and economic situation of the rural population, but also on the natural environment, structure of landscape and biodiversity. From ecological point of view, functions of rural areas are not only being a place for production of food, resources for industry and green energy, but also supplying environmental goods such as protection of biodiversity and influencing air and water quality as well as landscape. The author presents ways to reduce the pressure of agricultural activities on water resources in the region, catchment and farm scale.
\end{abstract}

Keywords: rural water development, soil and water conservation, sustainable agriculture, Baltic Sea protection, nitrate directive, rural environmental infrastructure

Sustainable development of rural areas is the way of managing which links economic, social and ethical principles with ecological safety. This may be reached by proper management, directed on cautious usage of ecosystems' self-controlling mechanisms, with the progress of science and technology. Apart from the above, natural resources should be exploited without interruption of the ability to their self-renovation. Increasing production of biomass may be treated as an effect of the increase in the productiveness of the resources, which means introduction of new technologies and, at the same time, protection of resources and retaining of the high quality resources for future generations.

Other definition of sustainable development could be as follows: Sustainable development means social progress combined with economic growth without entailing a rise in the entropy of the natural environment. The concept of entropy, derived from physics, is interpreted in environmental economics mainly as a relative measure of energy dispersed in the environment which cannot be profitably used and/ or of a chaotic dispersion of matter resulting in the same effect. In the light of the second law of thermodynamics, any economic activity not counteracted by appropriate measures to protect the environment adds to the growing entropy of the environment (cit. Czaja, 2001; Manteuffel Szoege, 2013). According to the law of entropy, pollution of the atmosphere and of surface waters propagates itself until it reaches a constant level over a given ecosystem. In rural areas, pollution is counteracted by the processes of natural absorption and degradation. These processes, if purposefully taken advantage of, are commonly called quantitative methods for the neutralization of pollutants and lead to a reduction in the concentrations of pollutants (Czaja, 2001 and Manteuffel Szoege, 2013).
Rural areas are not only places for agricultural production and farming, but also because of favourable environmental conditions, more common places for living, which would be impossible without an efficient modern infrastructure. The phenomena are benefiting from the changes of common agricultural policy aiming to create conditions for development of rural areas in the direction favouring the development of civilization. As a result of the support of civilization development on rural areas and construction of necessary infrastructure, the accessibility of the areas outside a city increases for more people. This results in an increase in property values and better management of land. This favours the rationalization of land use on rural areas and the competitiveness of agricultural production. In the past, the proper attention to the state and development of technical infrastructure was not paid. As a result, a barrier to the development of not only agricultural production, but also the development of rural civilization was formed.

A modern village is no longer synonymous with agriculture, but it is a place different from a city, a place for life and work of various groups of people, who apart from their diverse professions, form a community with common cultural issues, traditions, norms of coexistence and interests. Awareness and environmental sensitivity of the inhabitants of rural areas will be shaped not through orders and penalties, but foremost, by education. As long as farmers do not benefit from environmental protection, they will not be interested in maintaining clean environment.

\section{Rural areas in Poland}

Of the total area of Poland $\left(312,685 \mathrm{~km}^{2}\right), 168,000 \mathrm{~km}^{2}(54 \%)$ are used for agriculture and a further $89,000 \mathrm{~km}^{2}(28.5 \%)$ are covered with forests. The total population is 38.15 million 
inhabitants, of which the working population represents 13.5 million, $16.9 \%$ of whom are employed in the agriculture, hunting and forestry sectors. Rural areas cover over $93.2 \%$ of the area of Poland and are populated by 14.8 million people, i.e. $38.8 \%$ of the country's population. The area per person is 0.82 ha, out of which 0.09 ha per person in cities and 1.97 ha in the countryside (GUS, 2011).

An essential condition for the effective functioning of economy is the development of infrastructure, including technical infrastructure. Without roads, efficient transport, communications, water supply and energy the production is impossible in large areas. The lack of waste collection systems and sewerage systems threatens the natural environment and the functioning of rural settlement. One of the main difficulties in the development of infrastructure in rural areas is a large spatial dispersion. The total number of villages in Poland is 56803, including 42782 small villages and 14021 hamlets and settlements/colonies. In that number, rural villages inhabited by less than 100 people constitute 15\%,66\% are villages inhabited by 100 to 500 individuals, $13 \%$ by 500 to 1000 individuals and only $6 \%$ of villages are inhabited by more than 1000 people. According to the data of the Central Statistical Office, there is 18200 (32\%) compact villages (with distance between farms up to $45 \mathrm{~m}$ ), $27 \%$ villages with dispersed housing (just above $200 \mathrm{~m})$, and with intermediate distances between farms $-41 \%$ (GUS, 2013).

The confirmation of rank of these problems is the identification by the World Bank of the level of the rural areas equipment with technical infrastructure as a primary factor of development of rural areas and agriculture, among others documented due to a direct effect on the quantitative level of agricultural production, the overall development opportunities of these areas, to attract domestic capital and investment services. The EU policy conducted for many years on infrastructure development aims to create conditions of its availability in all EU countries in order to diminish the civilization gap, separating rural areas from urban areas, and to create equal opportunities of competitiveness in rural areas. An equally important aspect taken into account in its policy is to prevent the depopulation of rural areas, which has an adverse impact on the sustainable development of the countries.

The dispersed settlement, as well as a small number of inhabitants per village hinder the development of rural areas, increase the costs of infrastructure and frequently make it impossible to undertake non-agricultural activities. In recent years, a rapid decrease in the number of people earning their living in agriculture has been observed. Rural population obtains their income from many sources, mainly from paid employment. People living on old-age and disability pensions, especially in households with an agricultural holding user, account for a significant share of the rural population.

With regard to these data, it is clear why rural development is an important aspect of the development of the country. Major problems regarding rural development include:

- excessive employment in agriculture,

- fragmented farm structure,
- poor education,

- poor access to financial services,

- insufficiently competitive processing sector,

- underdeveloped rural infrastructure.

Since 1989, i.e. after the shift in political system, Polish rural policy and thus rural development has overcome many challenges and made several main changes. These include price liberalisation, opening up the national economy, removal of state subsidies for agricultural food products, establishments of major institutions responsible for government agricultural policy and, finally, the adjustments of policy needed to join the EU in 2004.

Agriculture in Poland is one of the most important sectors from an economic perspective and its importance is greater in Poland than in other countries in the EU. It has an influence not only on the social and economic situation of the rural population, but also on the natural environment, structure of landscape and biodiversity. However, the overall effect of agriculture on macroeconomic indicators is relatively small. In 2004, the share of agriculture in GDP was around $4.5 \%$ and in 2011 only 3\%. In 2011, income in rural areas per 1 inhabitant consisted by $80 \%$ of urban population. In rural population income, only $12 \%$ came from farming. In family farms, $68 \%$ of income came from farming activity. After the accession to the EU, agriculture production has increased by $17.5 \%$, rural population income by $114.4 \%$, and subsidies 12 times (GUS, 2011).

At present, with the financial support of the EU, the transformation of rural areas is underway. The EU is cofunding investments in agriculture and the environment and the implementation of comprehensive agrienvironmental programmes, including subsidies for farmers who implement environmentally friendly methods of production. The aim of these instruments is to stimulate multifunctional development of rural areas and modernize agriculture. However, the efficiency of implementation and consequently the capability to absorb the transfer of huge EU funding heavily depends on effective functioning of Polish institutions and administrations and the formulation of wise and deliberate policies. These policies should be supported with scientific evidence and knowledge (Motyka, 2007).

In general, development of agriculture and rural areas in Poland is currently working in three directions:

- price support and marked stabilization,

- subsidies for agricultural production and interest in intervention credits,

- structural policy for rural areas and agriculture.

Subsidies have been designated for soil protection, plant protection, biological improvement, and organic farming. Subsidized credit is available for purchase of agricultural land, management of agricultural holdings by young farmers, services to agriculture, fisheries, the agrifood sector and processing industry, restoration of holdings affected by natural disasters, investments in agriculture, food processing and creation of new jobs outside agriculture. 
Structural changes in agriculture and rural development are specified by macroeconomic policies aimed at economic growth, rising employment rates, education, reduction of poverty and maintenance of production potential and production volumes. These policies are based on equal development opportunities for all regions, as well as multifunctional rural development. A crucial issue has been to keep up with policies, which support natural resource utilisation and environmental protection.

The rural landscape in Poland is fascinating with its biodiversity. It is believed that this landscape is the best preserved in the EU on account of favorable natural conditions and unique anthropogenic influences such as uneven industrialization and urbanization, traditional extensive farming still being maintained in large areas and the existence of large old woods. The Polish landscape is characterized by a diversity of habitats with mosaic biological structure. There are about 365 different types of plant assemblages and about 45 types of plant habitats used as meadows and pastures are situated on agricultural land. Some agricultural land neighbouring to Nature 2000 programmes needs particular care.

Traditional production methods and spatial development patterns maintained to the present create an original cultural landscape with peculiar rural architecture complexes of traditional wooden houses, churches, chapels and communities, watermills and barns. Preservation of these buildings will contribute to the image of past and present Polish agriculture at local and regional level.

There are some unfavourable circumstances that can endanger good rural environment. Some of them have their origins in the past, for example cultivation of poor soils and soils susceptible to erosion, inappropriate water management in agricultural catchments, lack of education with regard to agricultural practices, lack of adequate agricultural equipment and pointsource heavy metal pollution of soil.

In recent decades there has been a marked decrease in populations of birds in farmland areas. It seems that the biggest threats are abandoning habitats that are of marginal importance for agriculture, simplification of landscape structure and excessive intensification of agricultural production. New threats have been recognized recently that are related to the failure of Good Agricultural Practice that farmers need to follow in order to fulfil agri-environmental requirements).

There are some negative aspects related to:

- changes in the traditional system of plant cultivation and animal breeding, resulting in intensified agricultural production,

- failure to cultivate grasslands, leading to the degradation and overgrowth of land, which in turn causes the disappearance of rare birds and plants,

- delay in the utilization of environmentally friendly agricultural production technology.

Rural areas are characterized by lower availability of basic technical infrastructure facilities when compared to urban areas, but, at the same time, funds allocated for this purpose increase rapidly. The adequate technical infrastructure in rural areas is of fundamental importance, and at the same time, it is difficult to be ensured due to its specific character, since rural infrastructure, as opposed to urban infrastructure, is:

- poorly concentrated;

- not intensive;

- often lacking spatial continuity;

- capital-intensive (due to long distances);

- poorly integrated

The indexes describing the coverage of rural areas with water supply and sewage network are definitely a better way to present the current situation. At the end of 2010, the water supply network coverage, calculated as a ratio of the number of residential buildings connected to the water supply system to the total number of residential buildings (in \%), was $79.7 \%$, while the sewage system coverage, expressed as a ratio of the number of residential buildings connected to the sewage system to the total number of residential buildings, amounted to $25.3 \%$.

\section{Multifunctional rural development}

Sustainable development of rural areas is the way of managing which links economic, social and ethical principles with ecological safety. This may be reached by proper management, directed on cautious usage of ecosystems self-controlling mechanisms, with the progress of science and technology. Apart from above, natural resources should be exploited without interruption of the ability to their self-renovation. Increasing of biomass production may be followed as a result of rise of recourses productiveness, which means introduction of new technologies and, at the same time, protection of resources and retain the high quality of the recourses for future generations (Mosiej, 2006).

Under present social and economic conditions, rural areas are more often places for: food production (plant and animal production), production of raw materials for industry, renewable sources of energy production, space for living and activity for urban population, space and conditions for flora and fauna, place for sport and recreation, water resources shaping, using and deposit of communal and industrial wastes, buffering and ecological compensation of nature anthropogenic and disorders in natural nature systems. From ecological point of view, functions of rural areas are not only production of food, resources for industry and green energy, but also supplying environmental goods such as protection of biodiversity and influencing air and water quality as well as landscape. According to the rules of sustainable development actions protecting and managing, in complex way, environment of rural areas, including water resources, should be taken under consideration in special planning and not violate the requirements of environmental protection. They should consider agricultural production space as well as living areas with their technical infrastructure and degraded areas and also protected areas including water biotopes. At present, socio-economic conditions require a new point of view on water factor in rural areas management, because about $80 \%$ of water pollution from rural areas come from sewage and improper storage of manure. The rural 
environmental protection infrastructure in farm scale is very important for the protection of water resources (Łabętowicz and Stępień, 2000).

Agriculture in Poland is one of the most important sectors from economical perspective and its importance is greater in Poland than in other countries in EU. It has an influence not only on social and economic situation of the rural population, but also on natural environment, structure of landscape and biodiversity. In 2010, there were 2278 thousand farms, from which $68.6 \%$ (1584 thousands) with area over 1 ha of agricultural land. Only 5.4\% farms operated on an area over 20 ha and in this $1.2 \%$ over 50 ha. Average size of one farm amounted to 7.92 ha. The share of agricultural land in Poland has decreased during last 50 years from $65.6 \%$ to $52.2 \%$, and arable land from $51.3 \%$ to $40.6 \%$ (GUS, 2011). During 2005, for infrastructure and others purposes was used 4100 ha (44\% for urbanization, $18 \%$ for industry, $10 \%$ for transport infrastructure, $11 \%$ for open mining and $17 \%$ for other purposes). It means that during one working day, 16 ha of area ( 2 average farms) was lost for the agriculture sector.

After the accession to the EU, the consolidation of agricultural production was observed in plant and animal production. In 2010 , over $80 \%$ of agriculture production was produced by $20 \%$ farms. Productivity of agriculture is low and constitutes $14 \%$ of this indicator in comparison to the EU-15. The agriculture effectiveness in macroeconomic indicators is relatively small and the share of agriculture in GDP is around 3\% (GUS, 2011). Low productivity results from the fragmentation of farms, unfavourable agricultural system, small economic capacity of agricultural holdings, excess of labour in agriculture, and finally insufficient equipment of agricultural holdings with modern machines and facilities.

Multifunctional model of rural development has to secure production of food, protection of natural resources and balance of energy production. The expected area for biomass energy production in Poland in 2020 will consist approximately of $2 \mathrm{mln}$ ha $(0.5 \mathrm{mln}$ ha of raps for biodiesel, $0.6 \mathrm{mln}$ ha cereals for bioetanol, $0.5-0.6 \mathrm{mln}$ ha of corn for biogas and $0.5 \mathrm{mln}$ ha of short rotation plantation for solid biomass energy). The expected biomass production for energy purposes will consist approximately of $10 \mathrm{mln}$ ton ( $2 \mathrm{mln}$ from forest, 3-4 $\mathrm{mln}$ straw and $5 \mathrm{mln}$ ton solid biomass from energy plantation). It means that $80 \%$ of biomass will come from agriculture sector (Budzyński et al., 2009; Kuś and Faber, 2009). For climatic conditions in Poland, a relatively high level of water demands for energy crops (especially willow) will be a limiting factor for development of energy plantation. The enlargement of energy crops area causes serious environmental threats, first of all, limitation of soil water resources that reduces the feed ground and surface waters (Borek, 2009; Mosiej et al., 2012).

\section{Urban rural flows}

The recirculation of nutrients between urban and rural areas is of great importance for sustainable agriculture. This is especially important for phosphorus, as phosphorus is a finite deposit with different estimates regarding the available amounts varying between 80 to 400 years. Phosphorus is a prerequisite for growing food and fodder. At the farm level, the phosphorus input should be of the same size as the amount of phosphorus removed. Phosphorus nutrient balances should be performed on a farm to show the size of the phosphorus surplus and should be used when planning fertilisation.

This also makes it necessary to have high quality rural area waste recirculated on agricultural land. It must not be polluted with heavy metals, organic compounds and other unwanted components. This also makes it important to involve a consumer in the process, as he or she must be aware that, depending on how he or she uses the toilet and sink, food quality can be affected.

Legislation is one means to make it possible to recycle human effluents back to agriculture. Different levels of legislation exist. For all countries in the EU, the EU directive on protection of the environment (especially the soil), when sewage sludge is used in agriculture, is relevant and can be considered to be the minimum level for legislation (Carlson, et al., 2000).

Urban areas in Poland have the surface area of 20.9 thousand $\mathrm{km}^{2}$, which amounts to $6.7 \%$ of the total surface area of the country, including the surface of inland waters. Rural areas cover 291.9 thousand $\mathrm{km}^{2}$, i.e. $93.3 \%$ of the total surface area. However, $70.6 \%$ of communal waste comes from urban areas (data from 2010), while 62\% of inhabitants live in towns. Approximately $370 \mathrm{~kg} \mathrm{year}^{-1}$ of communal waste per capita is produced in towns and only $240 \mathrm{~kg}$ year ${ }^{-1}$ per capita in rural areas (data fom 2010). Hence, much more communal waste is generated in towns than in rural areas, both in relative and absolute terms. This applies even more strongly to industrial waste.

In general, rural areas serve as the main receptor for emissions of pollutants from urban areas. Landfills are most frequently localised in rural areas for two reasons: because land is much cheaper in the country and landfill sites can be situated much farther away from residential areas. In this way, objections to localizations are much weaker and, additionally, raised by a sector of the population which possesses much less political and social power.

In particular, rural areas have also become receptors of urban pollutants in the case of agricultural utilisation of industrial sewage and field fertilization using urban sewer sludge or compost containing sewage sludge. About $21 \%$ from 533300 tons of urban communal sewage sludge in 2012 are utilised in agriculture and further $9.4 \%$ used to recultivation and $6.2 \%$ applied for cultivation of plants intended for compost or energy production (GUS, 2013). This serves as an example of the changing role of rural areas in our times. Their role has evolved quickly from that of foodstuffs producing areas to the role of a so-called ecological sink.

Green areas are more and more often treated as 'carbon parks' assimilating the carbon dioxide emitted by fuel burning. Simultaneously, traditional agriculture has been gradually becoming an obsolete branch of economic activity and is being replaced by industrial methods of food production. Farmers have been changing their roles from food producers to environmental guardians, who 
oversee the functioning of the environmental sink, as well as supplying environmental amenity services to the urban public. They also receive a growing proportion of their income for providing services of both kinds, e.g. from funds in the Polish agro-environmental programme (Dobrzyńska et al., 2004; Manteuffel Szoege, 2013).

\section{Water as an important factor of sustainable rural development}

Water is an important factor deciding about sustainable development of agriculture. It is caused by its function in agricultural landscape and the fact that its shortage or surplus impacts biodiversity especially in water reliable ecosystems.

During last few years, noticeable change of the way of thinking took place considering the management of water resources. Water was shown as "a restricted and sensitive resource, essential for sustaining of life, development and environment". While Water Framework Directive implemented a definition that shows water specifically as a resource: "water is not a product as any other but a hereditary good that has to be protected and treated as one". As a consequence of this approach, some priorities of water management has to be set to subordinate water economy to sustainable development rules which cause changes in rules and techniques of water resources management. In place of the aim oriented on usage and supplying of water for satisfying different parts of economy - there is the aim of sustainable usage and protection of not only water itself but also water ecosystems and water reliable ecosystems. As a basis of water resources management, integrated approach was taken, placed in natural, social and economic properties of water resources and connected to the environment (WWF, 2005).

According to the rules of sustainable development actions protection and management, in complex way, environment of rural areas, including water resources, should be taken under consideration in special planning and not violate the requirements of environmental protection. They should consider agricultural production space as well as residential areas with their technical infrastructure and degraded areas and also protected areasm including water biotopes. At present, socio-economic conditions require a new point of view on water factor in rural areas management. Water in agricultural landscape in spite of productive (production of biomass) function plays different roles such as (Mosiej, 2007):

- shaping of environmental conditions for habitats (soils process, microclimate),

- transport of chemical substances (solvent and medium) and energy (changes in state of water is connected with heat absorption or emission),

- landscaping and esthetic values,

- shaping of conditions for biodiversity protection (small reservoirs, ponds, wetlands, marshes, drainage grasslands in small river valleys),

- absorption, reception and reduction of anthropogenic treats caused by agricultural and urbanization activity (self-cleaning process).
About economic and ecological role of water does not decide its absolute amount but the time of water impact, time of taking part in different processes in landscape. On the other hand, this time depends on the level of the area covered by plants (biodiversity) and on the inflow time of rain water to rivers (Kędziora et al., 2005).

The role of water in landscape management cannot be seen apart from economic, social and ecological functions of rural areas nor without the context of the agricultural and ecological policy (state and regional scale) and also without the conditions caused by existing infrastructure connected with land improvement and water engineering. It should not be considered apart of special plans for management of existing habitats in rural areas (Rajda, 2005).

Plant production and forestry are the greatest water consumers in Poland. Riverine outflow equals to less than $30 \%$ of precipitation. More than $40 \%$ of precipitation is used by rainfed agriculture and $25 \%$ by forestry. Small area of irrigated crops does not mean little water consumption. Actually, over $5 \%$ of riverine flow is taken up by industry and municipalities. Most of this water, however, in a form of more or less treated sewage returns to the water cycle in contrast to the water taken up by vegetation, which is turned into water vapour as a whole. It is clearly seen that agriculture and water demands of plants in general (including forests) play a significant role in water cycling in nature. Therefore, the agriculture water resources are a key factor in implementation of the Water Framework Directive (Mioduszewski, 2006).

Agricultural water management infrastructure is very rich. It comprises, in particular, over $70000 \mathrm{~km}$ of rivers and channels included in the so called basic water infrastructure managed by state. Moreover, $280000 \mathrm{~km}$ of ditches are managed by owners of reclaimed areas. Noteworthy, at present some 100000 hectares are irrigated while several years ago irrigation involved the area of 500000 hectares (Mioduszewski, 2003).

Polish water resources depend on precipitations, which are variable in time and space. In dry years, the water balance is negative in central parts of Poland but sudden thaws and downfalls may result in periodical water excess and dangerous floods almost in the entire country. The retention capacity of artificial reservoirs in Poland permits to store only $8 \%$ of the average annual runoff, which is commonly considered insufficient. A real requirement of water storage capacity is $15 \%$ of average runoff. Another method to increase retention is soil water control. About fifty percent of soils in Poland consist of light and very light sandy soils with low water capacity. Loams and organic soils cover approximately $25 \%$ and $8.5 \%$ area of the country, respectively. Almost half of agricultural lands $(48 \%)$ have relatively good water conditions, but the rest requires soil water control measures. An increase of the soil water content could be achieved by changes of soil properties, water table control and soil water management. Modernization and reconstruction of drainage and irrigation systems, which were built mainly in the period 1960-1980, is needed. In total, $4.7 \mathrm{~m} / \mathrm{n}$ hectares of arable lands and $1.5 \mathrm{mln}$ hectares of grasslands were reclaimed. More than $90 \%$ of these areas were drained only. Irrigation 
systems are located mainly in river valleys as subirrigation of grasslands and cover about $0.4 \mathrm{mln}$ hectares, but recently subirrigation has been carried out on about $20 \%$ of these areas. On arable areas, sprinkler irrigation covers no more than 20 thousand hectares. Microirrigation is used in horticulture in the area of about 4 thousand hectares (Pierzgalski and Jeznach, 2006). There are also a few objects ( 5 thousand hectares in total) where border irrigation is applied utilizing waste water for agricultural purposes (Mosiej, 1999).

Due to climate change and related extreme meteorological and hydrological events (droughts), the scenario predicting an increase of both the irrigation water demand and irrigated areas is most likely. Nowadays, the role of irrigation in agriculture is marginal because of very small irrigated area ( $0.5 \%$ of the total agricultural land area). During the recent years, as well as in the years to come, three main factors exert an accelerating influence on the development of irrigation: increased frequency and intensity of droughts; the intensification of agricultural production (e.g. in horticulture, orchards, seed crops), being forced by the domestic and European free-market competition; the necessity of obtaining high quality of the majority of agricultural products (Łabędzki, 2009; Kaca et al., 2011).

\section{Will we have enough water to produce food?}

The main function of water in agricultural landscape is the productive function i.e. the biomass production. Therefore, we should manage water in the landscape in the way that allows it to do the maximum work, which is inter alia to produce a biomass. We have to remember that water is a solvent and a medium for substances and energy. Therefore, the approach to regulate and manage the water resources on larger areas should be very careful and cautious (especially when it regards drainage or irrigation). The increase of the outflow of water accelerates the circulation of water in the landscape influencing at the same time circulation (leaching) of mineral compounds, including the biogens.

The agriculture gains the water required for the production of plant biomass mainly from the precipitation. The size of the annual rainfall is beyond our control, but we can manage water in agricultural activities in a way ensuring the maximum production of plant biomass. Depending on the method of water management in the fields, we can obtain significantly different yields of crops. In order to identify, at least approximately, the opportunities of the plant biomass production depending on water resources in Poland, we have to begin with balancing its total resources available in our country. With app. $190 \mathrm{~km}^{3}$ (190 billion $\mathrm{m}^{3}$ ) of water originating from the precipitation, the crop transpiration consumes about $68 \mathrm{~km}^{3}$, and the river runoff to the Baltic Sea $-58 \mathrm{~km}^{3}$. The remaining $64 \mathrm{~km}^{3}$ of water is consumed by the woods (about $50 \mathrm{~km}^{3}$ ), natural evaporation from the surface of plants (interception) and soil (evaporation) (GUS, 2013).

Water is especially important for agriculture in dry climate. The amount of water and its availability determines the possibility of conducting any agricultural production.
The quantity of water used in agriculture can be presented by the fact that $10000 \mathrm{~m}^{3}$ of water is sufficient for (Carruthers and Clark, 1983):

- irrigation of 1 ha of rice plantation, 1.6 ha of cotton and $\sim 2$ ha of wheat in dry climates,

- the water supply for 100 nomads and 450 cattle units for 3 years,

- the water supply for 100 villagers that use primitive draw wells for 14 years,

- the water supply for 100 villagers that use water supply system for 4 years,

- the water supply for 100 consumers in a modern industrial city for 2 years,

- the water supply for 100 guests of luxury hotel for 55 days.

The greatest amounts of fresh water absorb the food production, especially production of biomass. Crops absorb relatively large amounts of water for the production of biomass or transformation of radiant energy from the Sun into a chemical energy of biomass with the involvement of the soil with the efficiency of 1 to $3 \%$. Water availability significantly affects the efficiency of this process. Thus, water is essential to produce a certain volume of biomass, which is a raw material (feedstock) for food production. Scientists have calculated that the demand for water in litres, per unit of measurement of the product before it reaches the stores. In the future, the number of countries that can afford to produce food will diminish; the import of food will be more profitable. Countries with low water resources, suffering from the shortages, are looking for such technologies of plant cultivation, which reduce the consumption of this precious resource to minimum. Therefore, to avoid losses due to excessive evaporation of water, many plants are grown under plastic. The whole fields are being rebuilt, on the model of the cultivated rice fields in Asia.

Still, we sometimes do not think of the amount of consumed water for the food production. For example, the production of one slice of bread $(30 \mathrm{~g})$ consumes up to $40 \mathrm{dm}^{3}$ (litres) of water, and if we add 10 grams of cheese, the sandwich absorbs $90 \mathrm{dm}^{3}$ of water. If such a breakfast is followed by a cup of coffee, then we should add to the calculation 140 litres of water, if it is a cup of tea - 35 litres. In total, our modest breakfast absorbs in total 130-230 litres of water. The total amount of water needed to produce $1 \mathrm{~kg}$ of poultry meat is about $3.9 \mathrm{~m}^{3}$, sheep meat $-6 \mathrm{~m}^{3}$, and beef even up to $16-18 \mathrm{~m}^{3}$ of water. Experts have calculated that the production of $3000 \mathrm{kcal}$ of vegetarian food needs about $1.5 \mathrm{~m}^{3}$ of water, whereas the meat diet needs $3.5-4 \mathrm{~m}^{3}$ per day (Chapagain and Hoekstra, 2004). Improving the quality of food, including increase of the share of meat in the diet will cause the production of food for a growing world population, which will cause a sharp increase in water consumption.

The analysis conducted for the 15 EU countries showed a decrease in water consumption for the food production in the last 30 years. This is due to the changes in diet, lower consumption of meat (especially from beef to poultry), directed to the vegetarian diet. But the main important factor limiting the use of water is the biological progress in 
grain production (more favourable ratio of grain weight to the total weight of a plant).

\section{Assessment of environmental impact}

The state of the environment in rural areas depends on the method of agricultural production. Many valuable habitats were created thanks to the traditional ways of farming, pastures and regular mowing. In the long term, the intensification of agriculture leads to greater water and soil pollution, disturbance of the environmental equilibrium, lower quality of agricultural produce and of the environment, as well as less biodiversity. There are two competing aspects of agricultural influence to the natural environment. The positive aspects are long-lasting; agriculture shapes the mosaic and diverse landscape as well as guarantee good conditions for diversity of plants and animals. The negative aspects are that agriculture degrades the environment to some extent through excessive fertilization, non-adjusted agricultural techniques and non-compliance with good agricultural practices. Important aspect, deciding on sustaining development of agriculture and rural areas is water. It is because of the role of water in agricultural landscape as well as the fact that its excess or shortage impacts biodiversity, especially in the water depending ecosystems.

Nitrate pollution of waters is a major cause of the eutrophication of coastal waters and results in surface water and groundwater resources in Europe not meeting the requirements of the Water Framework Directive (WFD). According to the WFD, there is a broad range of tools that serve to minimize the influence of agriculture on the environment. It is typical to choose a number of instruments that work on various scales, beginning from catchment areas and river basins, to the actions taken on the scale of a farm. All of the instruments need to have an appropriate legal basis. In addition to this, these instruments should be assisted by a system of data collection and storage, in order to assess the effectiveness of actions from the point of view of the environment, society and the economy.

The impact of agriculture on the environment is significant because, unlike other economic activities, farming forms part of the ecosystem rather than being external to it. Agriculture utilizes the natural environment to produce food through a range of different practices, such as land drainage, tilling of soil, diverting natural water sources, irrigation and applying nutrients and pesticides. These practices affect soil, air, water, biodiversity and landscapes. Water quality is a major environmental concern in Europe.

Potential agricultural pressure on water quality is indicated by the "gross nitrogen balance"'. This indicator relates to the potential surplus of nitrogen in agricultural land. This is estimated by calculating the difference between the amount of nitrogen added to an agricultural system and the amount of nitrogen removed from the system per hectare of agricultural land. The gross nitrogen balance indicator accounts for all inputs and outputs on a farm, and includes all residual emissions of nitrogen from agriculture into soil, water and air. Nitrogen remains of approximately $30-35 \mathrm{~kg} \mathrm{ha}^{-1}$ in Poland in the period 1991-2000 according to the Code of Good Agricultural Practice were on a satisfactory level. In the EU-15 countries, the mean gross nitrogen balance in 2000 was calculated to be $55 \mathrm{~kg} \mathrm{ha}^{-1}$, which is $16 \%$ lower than the 1990 estimate of $66 \mathrm{~kg} \mathrm{ha}^{-1}$. In 2000, the gross nitrogen balance ranged from $37 \mathrm{~kg} \mathrm{ha}^{-1}$ (Italy) to $226 \mathrm{~kg} \mathrm{ha}^{-1}$ (the Netherlands) (EEA, 2006). In the case of Poland, the mean gross nitrogen balance for the years 2002-2004 was calculated to be $45 \mathrm{~kg} \mathrm{ha}^{-1}$ varying from $16.1 \mathrm{~kg} \mathrm{ha}^{-1}$ in the dolnośląskie (Lower Silesia) voivodship to $75.2 \mathrm{~kg} \mathrm{ha}^{-1}$ in the kujawsko-pomorskie (Pomerania, northern Poland) voivodship (Kopiński et al., 2006). In the podlaskie (Podlasie, eastern Poland) voivodship, the index is close to the average level in Poland and at $43.7 \mathrm{~kg} \mathrm{ha}^{-1}$. The availability of regional gross nitrogen balances could provide much better insight into the actual likelihood of nutrient losses to water bodies, when combined with data on farm management practices, as well as climatic and soil conditions (EEA 2006).

The yearly ammonia emission in Europe (Sapek, 1995) has been estimated at about 8 million tons; from this, over $72 \%$ of $\mathrm{NH}_{3}$ is of agricultural origin, first of all as a result of animal production and further organic fertilizers management. In Poland, $90 \%$ of the total ammonia emissions (estimated between 0.4-0.6 million $\mathrm{t}$ yearly) have animal wastes origin. Ammonia in the air can be a reason for many negative occurrences such as serious changes in the ecosystem in consequence of the nitrogen excess, which can cause the extinction of many plant species of poor soils, the excessive soil acidifying as a result of nitrification processes, eutrophication and acidifying of subterranean and superficial waters in the water ecosystems, the disappearance of natural proprieties of forest-ground soil methane absorption and even faster devastation of buildings facades in consequence of intensively growing bacterium and fungi activity (Dach and Pietrowski, 2004).

\section{Protecting the quality of water in rural areas}

Activities leading to improvements in the quality of shallow ground waters can be divided into the three groups (Balla, 2007; Dobkowski and Skopiec, 2003):

- the building of tanks for liquid manure and applying environmentally friendly techniques to spread it on green areas and arable land, which requires farm infrastructure for the development of environmental protection and active protection of water resources, i.e. limiting pollution in situ;

- the building of deep wells and proper localization of shallow wells, activities which enable making clean, unpolluted water accessible to people living in areas where water is already degraded;

- the purification of water rich in biogens, flowing out from the agricultural catchment area, before it reaches larger water basins like: buffer zone, artificial wetlands, water ponds. 
The problem of the development of infrastructure has to be considered in its financial, technological, environmental, social, cultural, political and legal aspects. Appropriate solutions and technological projects, which enable meeting the requirements of the EU, have to be implemented. Determination of appropriate actions for the protection and use of water resources in rural areas needs a precise assessment of the interaction between water resources, the environment and agriculture, both positive and negative (Pierzgalski, 2002). The investment process has to be overseen - to make the most of financial funds. Poland has to be competitive within the EU to make the real integration of Poland into the EU.

Proper manure management diminishes the danger of pollution. Positive environmental effects are not visible immediately after building containers for the proper storage of animal manure. However, a better quality of surface waters and shallow groundwaters, rain of lower acidity, decreased global warming - will become noticeable after a few years (Dobkowski and Skopiec, 2003). Implementation of such a programme in Denmark in 1987, whose aim was to limit water pollution by nitrate compounds, enabled a $28 \%$ reduction in nitrate loss from agriculture and retention of $50 \%$ of the nitrates in farms. Within agricultural river basins, a $20 \%$ reduction in the pollution of inflowing waters has been noticed. The eutrophication process has also been reduced. A Swedish programme for limiting nitrate emissions into water from agriculture used several instruments, leading to a reduction of $50 \%$ in nitrate pollution from rural areas. This investigation shows that, apart from extensive farming, the most effective way of limiting such pollution is appropriate manure management and lack of relevant infrastructure in the farm scale (Gren at al., 1994).

\section{Study sites and methods}

Liquid and solid manure, as well as slurry, are natural fertilizers rich in nutrients. Therefore, when they are used appropriately in accordance with local climatic and soil water conditions, they contribute to increased yields and lower production costs. In the case of agricultural use, it is important not to overfertilize plants and predict climatic conditions. Non-sustainable fertilizing with slurry and manure leads to increased water pollution. The collection and storage of manure in permeable or insufficiently large containers results in the point pollution of surface and ground waters. Sewage from agricultural production is rich in organic matter. The biological oxygen demand (BOD) for liquid manure is 50 times greater than for raw municipal sewage. When high BOD sewage flows into a river, the level of dissolved oxygen immediately decreases. This can result in the death of fish and invertebrates.

\section{a) The Baltic Sea pollution}

According to data, farm animals in Poland produced approximately $120 \mathrm{mln}$ tons of faeces annually (slurry, solid and liquid manure) in 2010. This corresponds to a yearly production of 450000 tonnes of nitrates and 255000 tonnes of phosphorus (GUS, 2013). When the rules of proper manure management are not respected, contamination of natural environment may occur. Improper storage of manure (storage of solid manure on the ground and the use of permeable containers for the collection and storage of slurry and liquid manure) is a reason for $20-30 \%$ losses of nitrogen (90 000-135 000 tonnes annually) and 10-12\% losses of phosphorus (25 000-30 000 tonnes annually). It is estimated that annually 139700 tons of nitrogen and 9100 tons of phosphorus are emitted from Poland into the Baltic Sea. Around $50-60 \%$ of this nitrogen and $40 \%$ of this phosphorus comes from agriculture. Manure accounts for $43 \%$ of the fertilizer used (Dobkowski and Skopiec, 2003).

The Ministers of the Environment and Senior Government Officials of the Member States of HELCOM met on $15^{\text {th }}$ November 2007 in Krakow, Poland, to adopt an ambitious overarching action plan to drastically reduce pollution emissions into the Baltic Sea and restore its ecological state. The key component of this is to reduce nutrient loads and allocate these reductions to the countries in the region. At this meeting, it was decided that emissions from Polish rivers into the Baltic Sea should be reduced by 83,000 tonnes $\mathrm{N} /$ year and 8,800 tonnes P/eayr. Thus, there is an urgent need for water managers in Poland to identify the most appropriate measures to meet this target. Moreover, nutrient management and analysis of the sources of pollution by agricultural nutrients will be a key challenge in the implementation of the Water Framework Directive (WFD).

\section{b) The results of a survey}

The Podlaskie voivodship is called the Green Lungs of Poland. This is because of the fact that 472173.8 ha of forests are under protection. Parallel to the network of protected landscapes, the European Nature 2000 network covers a part of the voivodship. The surface water resources of the voivodship are created by 330 rivers, lakes, ponds, canals and artificial reservoirs. In this area, there are no surface waters of very good or good quality. Among the 92 monitored points, the water quality is threatened by eutrophication in 24. According to the "Programme of Environmental Protection in the Podlaskie Voivodship 2007-2013", the main threat to the state of surface waters is pollution arising from improper sewage management. The quality of groundwater is good. In $27 \%$ of the monitored points, water was suitable for drinking. One of the main threats to groundwater is improper manure management (especially slurry management).

The Nitrates Directive obliges member states to designate areas as Nitrate Vulnerable Zones or NVZs. To comply with the Nitrates Directive, Poland has designated 21 areas in 6 regions as NVZs in 2004. The total area of these NVZ is $6263 \mathrm{~km}^{2}$, which comprises $\approx 2 \%$ of the total area of the country. This is small in comparison to the United Kingdom $\approx 38.4 \%$, France $\approx 44 \%$, but more than in Portugal $\approx 1.2 \%$. In the area of the Regional Water Management Board (RWMB) in Warsaw, NVZs cover $1.53 \%$ of the total area. According to hydrogeologists, the whole of Sandr Kurpiowski, which lays in this RWMB is extremely vulnerable to pollution from agriculture. Apart from the above, $60 \%$ of the area is covered by light - textured (sandy) soils, which are vulnerable to nitrate leaching. No NVZs have been designed in the Podlaskie voivodship. It seems 
reasonable to test the criteria used in designating NVZs (Alterra, 2007).

In 2006, an anonymous survey was conducted in the Łódzkie, Opolskie, Podlaskie and Pomorskie regions. Farmers participating in training courses on "The Code of Good Agricultural Practice", organized within the Sectorial Operational Programme for Restructuring and Modernization of the Food Sector and Rural Development, were questioned about infrastructure used on farms for environmental protection and compliance with the Code of Good Agricultural Practice. As much as 2582 rural farms took part in the survey, of which 1729 from the Podlaskie voivodship were considered for further analysis. The survey confirmed the problems. No more than six percent of sewage is directed into municipal wastewater treatment plants via sewage systems. Sixty six percent of farms are equipped with septic tanks, among which only five percent have an agreement about sewage collection. Seven percent of farms have their own wastewater treatment plants. The results of the survey showed a lack of containers for liquid manure storage and containers for preventing leakage from manure pads on $81 \%$ and $55 \%$ of farms, respectively (Wyporska and Mosiej, 2010).

\section{Resume}

Sustainable agriculture is of fundamental importance to mankind, producing not only food and fiber but also, through its interaction with land and natural resources, performing vital functions such as nutrient cycling and carbon storage. In Poland, traditional farming was small-scale, subsistent in nature and sympathetic to natural environment. Indeed, traditional, low input forms of agriculture have helped to create the variety of landscapes and associated wildlife that are highly valued by citizens today. But with population growth, the introduction of new technology encouraged by public policy, agriculture has become increasingly intensive and industrialized, resulting in negative impacts on the environment. The loss of habitats, declines in wildlife, drainage of wetlands, agriculture use of valleys, groundwater abstraction, soil erosion and water pollution are just some of the problems we now face as a result of modern agriculture. Climate change brings a new challenge; agriculture will need to adapt to a changing climate.

Agriculture in Poland is one of the most important sectors from economical perspective and its importance is greater in Poland than in other countries in the EU. It has an influence not only on social and economic situation of the rural population but also on natural environment, structure of landscape and biodiversity. Water is an important factor deciding about sustainable development of agriculture. It is caused by its function in agricultural landscape and the fact that its shortage or surplus impacts biodiversity especially in water reliable ecosystems.

Of all the countries around the Baltic, Poland still has quantitatively the biggest impact on the environment of this sea area. There are several reasons for this. Almost the whole area of Poland falls within the Baltic drainage basin, and additionally, almost half of the population and $40 \%$ of the arable land of the basin as a whole are to be found within the country's borders. Of the nutrients discharged by the
Vistula alone, $60 \%$ of nitrogen and $40 \%$ of the phosphorus come from rural areas.

Necessary condition of introduction of the pro-ecological actions in rural areas is the ecological consciousness of farmers and inhabitants of rural areas. The consciousness of the inhabitants of the rural areas should be shaped not through orders and punishments, but mainly through education. Until farmers do not feel the positive effects coming from protecting the environment, they will not be interested in keeping clean environment. Still, the problem of costs is going to appear at a certain stage. This additional cost will increase the cost of production. At this moment, financial grants will be necessary. In the European Union, such incentives have been used successfully for a long time.

Farmers have to be willing and able to introduce actions that serve environmental protection. The most important condition for the success of actions is the relationship of farmers to the environment. The influence of agriculture on environment depends on the long-term and short-term decisions of farmers regarding manure management. The environmental effects of these decisions result in the integration of economic aims with good agricultural practice, available technologies and their use in the context of the possibilities and limitations of the political and economic situation. Subsidizing investments in infrastructure at the scale of farms has to be supported by training informing society on the importance of actions that serve environmental protection and the sustainable development of rural areas.

A review of problems concerning water management in rural areas shows that there are numbers of contemporary conditions, which on the one hand limit the improvement of poor condition of water infrastructure, but there also are others, forcing a positive change in this regard. To the first group of factors determining the current state of water measures should be included the general state of agriculture and the efficiency of farms. Production restrictions related to the Polish accession to the European Union, the need of competition in the market for agricultural products and poor economic condition of farms undoubtedly shape the process of degeneration of water facilities and the demand for precise water management. Among the forcing factors there is the need to achieve the objectives of the European Union Directives, between others the Frame Water Directive. In case of controlling the predictions of climate change, and in particular global warming very seriously, programmes to combat drought, including investments in water retention, water-saving irrigation, upgrading drainage systems etc. need to be implemented. Water management in rural areas, carried out mainly by local government on the regional or local level differ significantly from the objectives and tasks of water management implemented by the government for the whole country or major river basins. Nowadays, the main attention should be concentrated on implementing of concepts of such activities that could show the most appropriate ways of special planning of agricultural areas in catchments scale in aspect of possibility of improving existing environmental status and water resources. 
The Podlaskie voivodship is a region of great importance to the nature of Poland. The survey showed that there are still vast investment needs regarding equipping farms with infrastructure for environmental protection, both for sewage management and storage of manure. It is important to answer the question: what kind of infrastructure is needed in rural areas to assure a balance between social and economic growth? At the same time, the resources of the environment should not be degraded. The development of infrastructure in rural areas is supported by structural funds from the European Union within its regional policy. Actions should be aimed at improving the quality of life by creating employment while showing respect to the social and economic aspects of these actions and multifunctional development of rural areas. One of the priorities of such development is environmental protection.

\section{References}

ALTERRA. 2007. Assessment of the designation of nitrate vulnerable zones in Poland. In Environmental Sciences, Report, Wageningen University \& Research Centre.

BALLA, G. 2007. Wetland establishment on areas endangered by un-drained runoff. In Zeszyty Naukowe PTIE i PTG Oddział w Rzeszowie, 2007, no. 9, pp.7-12.

BOREK, R. 2009. Wpływ uprawy wierzby i miskanta na bilans wody w glebie. In Post. Nauk Rol., 2009, no. 5-6, pp. 97-108.

BUDZYŃSKI, W. - SZCZUKOWSKI, S. - TWORKOWSKI, J. 2009. Wybrane problemy z zakresu produkcji roślinnej na cele energetyczne. In Przyszłość sektora rolno-spożywczego i obszarów wiejskich. Wyd. IUNG-PIB, 2009. pp. 77-88.

CARRUTHERS, I. - CLARK, C. 1983. The economics of irrigation. Liverpool : Liverpool University Press, 1983.

CARLSON, G. - JAKOBSSON, CH. - STEINECK, S. 2000. Urban rural nutrients flows. In Water Use and Management, Uppsala University, 2000. pp. 101-110.

CHAPAGAIN, A. K. - HOEKSTRA, A. Y. 2004. 'Water footprints of nations : Main Report', Value of Water Research Series. UNESCOIHE, vol. 1, 2004, no. 16.

CZAJA, S. 2001. Zarys koncepcji entropijnie zrównoważonego rozwoju. In Piontek, F. (ed.). Ekonomia a rozwój zrównoważony. Teoria i kształcenie, Białystok : Wydawnictwo Ekonomia i Środowisko, 2001. pp. 157-166.

DACH, J. - PIETROWSKI, M. 2004. The Research on Ammonia Emissions from the Manure during Storage, Composting Process and Spreading on the Field. In Elimination of Agricultural Risks to Health and Environment. http://www.itep.poznan.pl/ monografia/dzial-24.html

DOBKOWSKI, A. - SKOPIEC, B. 2003. Podstawowe zasady realizacji inwestycji w zakresie ochrony środowiska w rolnictwie i zagospodarowania odchodów zwierzęcych. Warszawa : NFOŚiGW, 2003.

DOBRZYŃSKA, N. - JOBDA, M. - KLISOWSKA, A. - LIRO, A. SZEMPLIŃSKA, M. 2004. Przewodnik po Krajowym Programie Rolnośrodowiskowym. Warszawa : Agencja Reklamowo Wydawnicza "Skigraf", 2004.

GREN, I. M. - ELOFSSON, K. - BYSTROM, O. - PETRINI, F. - UHLIN, H. E. 1994. Measures to reduce the agricultural load of nutrients to the Baltic Sea. Background paper for the workshop Jan.
14-16, 1994 at Royal Swedish Academy of Sciences, Stockholm (manuscript), 1994.

EEA. 2006. European Environment Agency. Integration of environment into EU agriculture policy - the IRENA indicatorbased assessment report.

GUS. 2011. Rural areas in Poland. Main Statistical Office.

GUS. 2013. Environmental Protection 2013. Main Statistical Office.

KACA, E. - ŁABĘDZKI, L. - LUBBE, I. 2011. Gospodarowanie wodą W rolnictwie w obliczu ekstremalnych zjawisk pogodowych. In Post. Nauk Rol., 2011, no. 1, pp. 37-49.

KĘDZIORA, A. - RYSZKOWSKI, L. - PRZYBYŁA, Cz. 2005. Ochrona i kształtowanie zasobów wodnych i ich jakości w krajobrazie rolniczym. In Gospodarowanie wodą w Wielkopolsce, Wyd. ABRYS, 2005. pp. 16-25.

KOPIŃSKI, J. - TUJAKA, A. - IGRAS, J. 2006. Nitrogen and phosphorus budgets in Poland as a tool for sustainable nutrients management. In Acta Agriculturae Slovenica, 2006, no. 1, pp. 173-181.

KUŚ, J. - FABER, A. 2009. Produkcja roślinna na cele energetyczne a racjonalne wykorzystanie rolniczej przestrzeni produkcyjnej Polski. In Przyszłość sektora rolno-spożywczego i obszarów wiejskich, Wyd. IUNG-PIB, Puławy, 2009. pp. 63-75.

ŁABĘTOWICZ, J. - STĘPIEŃ, W. 2000. Zagrożenia związkami pochodzącymi z rolnictwa. In Problemy ochrony środowiska na obszarach wiejskich" SGGW, 2000. pp. 59-76.

$Ł A B E ̨ D Z K I, L .2009$. Expected development of irrigation in Poland in the context of climate change. In J. Water Land Dev., 2009, no. 13b, pp. 17-29.

MANTEUFFEL SZOEGE, H. 2013. Sustainable development in rural Poland from the perspective of environmental economics. In Economic and Environmental Studies, vol. 13, 2013, no. 3, pp. 265-278.

MIODUSZEWSKI, W. 2006. Management of water resources in rural areas: the Polish approach. In J. Water Land Dev., 2006, no. 10, pp. 3-14.

MIODUSZEWSKI, W. 2009. Water for agriculture and natural environment, In J. Water Land Dev., 2009, no. 13b, pp. 3-16.

MOSIEJ, J. 1999. Przyrodniczo-techniczne uwarunkowania gospodarowania wodą $w$ dolinie rzeki Ner. Wyd. SGGW, Monogr., 1999, no. 222, p. 160.

MOSIEJ, J. 2006. Problemy rozwoju zrównoważonego w kształtowaniu obszarów wiejskich. In Problemy Ekologii, 2006, no 5, pp. 253-258.

MOSIEJ, J. 2007. Woda jako czynnik kształtujący przestrzeń obszarów wiejskich. In Biul. KPZK PAN, 2007, no. 243, 2007, pp. 208-216.

MOSIEJ, J. - PIERZGALSKI, E. - JEZNACH, J. 2011. Współczesne uwarunkowania gospodarowania wodą w obszarach wiejskich. Contemporary issues of water management in rural areas. In Post. Nauk Rol., 2011, no. 1, pp. 25-36.

MOSIEJ, J. 2011. Rural water management as important factor of sustainable rural development in Poland - some aspects. In Rural Development 2011 : proceedings : the Fifth International Scientific Conference, Akademija, Kaunas, vol. 5, 2011, Book 2, pp. 326-331.

MOSIEJ, J. - WYPORSKA, K. 2012. Sustainable rural water management - selected aspects. In Natural human environment : dangers, protection, education : monograph / ed. K. Dyguś, Warsaw, Oficyna Wydawnicza Wyższej Szkoły Ekologii i Zarządzania, 2012. pp. 367-380. 
MOSIEJ, J. 2012. Policy of Rural Development in Poland. In Rural development and land use, Baltic University Press, 2012. pp. 274-276.

MOSIEJ, J. - Karczmarczyk, A. - Wyporska, K. 2012a. Landscape and maintenance of water resources. In Rural development and land use, Baltic University Press, 2012. pp. 234-242.

MOSIEJ, J. - KARCZMARCZYK, A. - WYPORSKA, K. - RODZKIN, A. 2012 b. Biomass production in energy forests: short rotation plantations. In Rural development and land use, Baltic University Press, 2012. pp. 196-202.

MOTYKA, K. 2007. The EUruralis is approaching, what do we do? In Policy-science interface in rural development practice in Poland. MSc thesis, Warsaw University of Life Sciences-SGGW, Interfaculty Department of Environmental Protection, 2007. p. 132.

PIERZGALSKI, E. 2013. European Union Policy in Aspects of Rural Areas Development. EU Agrarian Law, 2013. pp. 14-21.

PIERZGALSKI, E. - JEZNACH, J. 2006. Measures for soil water control in Poland. In J. Water Land Dev.,2006, no. 10, pp. 79-89.

PIERZGALSKI, E. 2002. Ograniczenia w gospodarowaniu wodą na obszarach dolinowych wynikające $z$ konwencji i programów ochrony przyrody. In Wiad.Melior. i Łąkar., 2002, no. 3, 2002, pp. 128-131.
RAJDA, W. 2005. Woda w zagospodarowaniu przestrzennym obszarów wiejskich. In Post. Nauk Roln., 2005, no. 3, pp. 33-42. SAPEK, A. 1995. An ammonia emission from agricultural production. In Postępy Nauk Rolniczych, 1995, no. 2, pp. 3-23.

SWATOŃ, J. - ROGOWSKI, R. J. 2002. Informacja o projekcie "Ochrona Środowiska na Terenach Wiejskich" - doświadczenia i nauki płynące z Polski. In Materiały z seminarium "Ograniczenia zanieczyszczeń pochodzenia rolniczego-wzorcowa praktyka", Przysiek k/ Torunia NFOŚiGW, 2002.

WWF POLSKA, GWP POLSKA. 2005. Zasady gospodarowania na obszarach NATURA 2000 w dolinach rzek. Warszawa, 2005.

WYPORSKA, K. - MOSIEJ, J. 2010. Technical infrastructure for environmental protection at the level of farms as a factor of sustainable rural development. In Economic and Environmental Studies, vol. 10, 2010, no. 1 (13), pp. 71-84.

\section{Contact address:}

Prof. Józef Mosiej, Warsaw University of Life Sciences - SGGW, Faculty of Engineering and Environmental Sciences, Department of Environmental Improvement, ul Nowoursynowska 166, 02-7, 76 Warsaw, Poland, e-mail: jozef_mosiej@sggw.pl 